\title{
Rivalitas Iran-Saudi-Turki dan Kekhawatiran Ideologis Kaum Wahabi Indonesia terhadap Kesepakatan Nuklir Iran-AS
}

\author{
Al Chaidar \\ Universitas Malikussaleh, Aceh \\ alchaidar@gmail.com \\ Herdi Sahrasad \\ Universitas Paramadina, Jakarta \\ sahrasad@yahoo.com
}

\begin{abstract}
The Iran-US agreement on nuclear power has made watershed in Iran-West relations, in which all of nuclear weapons of Iran should be disconnected and frozen so that only the Israelis held a nuclear power in the Middle East.Teheran always says its nuclear activities are for peaceful purposes. Nowadays the international sanctions on Iranian lifted, and Iran is more powerfull to enhance its posture in international arena.

This agreement has caused ideological anxiety among the Wahabis with implications that the Wahabis are not happy and they do not like with the strengthening of Iran politically and culturally in globalized world. The Wahabis' Ideological interests will be eroded to a certain degree with the agreement which would seriously divide the Islamic world by by Sunni-Shia rivalry. However, the rise of Turkey which competed with Iran and Saudi in the political arena of Middle East, would open the Wahabis eyes in Indonesia that maybe Turkey is the hope of the future.
\end{abstract}

Keywords: Iran, Saudi, Sunni, Syiah, Turki, Islam, nuklir, AS

\section{Pendahuluan}

Kesepakatan Nuklir Iran telah dicapai di Wina, Austria, pada
Juli 2015. Pertemuan tersebut merupakan hasil panjang diplomasi yang akhirnya dimenangkan oleh 
Iran setelah banyak ilmuwan nuklirnya terbunuh. Kesepakatan ituakan mengubah komposisi geopolitik dunia. Kekuatan dunia telah mencapai kesepakatan dengan Iran dalam mengurangi kegiatan nuklir negara itu dengan imbalan pencabutan sanksi atau embargo ekonomi internasional yang telah berlangsung tiga dekade.Presiden Amerika Serikat Barack Obama mengatakan dengan kesepakatan tersebut, semua senjata nuklir Iran telah diputus bagi Iran sehingga kekuatan nuklir Timur Tengah tetap dipegang secara militer oleh Israel.

Bagi Presiden Iran, Hassan Rouhani, hal ini membuka "bab baru" hubungan Iran dengan dunia, sebuah peluang yang telah lama ditunggu-tunggu wangsa Persia ini. Perundingan antara Iran dan enam kekuatan dunia (Amerika Serikat, Inggris, Prancis, Cina, Rusia ditambah Jerman) dimulai pada tahun 2006. Negara-negara P5+1 menginginkan Iran mengurangi kegiatan nuklir yang merupakan isu krusial untuk memastikan negara tersebut tidak bisa membuat senjata nuklir.

Kekhawatiran ideologis (ideological anxiety, restlessness and worry) kaum Wahabi -yang akhir-akhirnya ini menguat setelah munculnya Al Qaeda dan ISIS sebagai wakil dari kedigdayaan
Wahabi- adalah kekhawatiran kultural yang serius akan dunia Islam yang terpecah. Garber (1997) membuktikan bahwa kepentingan personal yang sangat ideologis pun akan menghasilkan kecemasan kultural yang akut. Pastilah kepentingan komunal Wahabi di Indonesia sangat besar atas menguatnya Iran secara politik dan kultural (Garber, 1977).

Lihatlah situasi dimana kekuatan Iran yang dibenci oleh kaum Wahabi di Indonesia selalu mengundang kecemasan kultural yang menyesakkan dada para pencari surga ini.Iran, yang menginginkan sanksi internasionalnya dicabut, selalu mengatakan kegiatan nuklirnya untuk tujuan damai.Kondisi ini tidak lantas membuat kaum agamawan Suni bersimpati dengan Iran yang nota-bene adalah negara pengusung ideologi Syiah.Pun, terdapat penolakan keras dari kelompok konservatif baik di Iran maupun Amerika Serikat. Kongres AS memiliki waktu selama 60 hari untuk memertimbangkan kesepakatan itu, meskipun Obama mengatakan akan menveto usaha untuk menggagalkan.

Kaum Wahabi di Indonesia mengalami kegamangan dalam melihat perkembangan diplomasi Iran di dunia dan juga di Indonesia. 
Pada tataran dunia, perundingan nuklir Iran dengan kelompok P5+1, yaitu lima negara anggota tetap Dewan Keamanan (DK) PBB (Amerika Serikat, Inggris, Perancis, Rusia, dan Cina) ditambah Jerman serta Komisaris Tinggi Kebijakan Luar Negeri Uni Eropa akhirnya menemukan titik final setelah 22 bulan berjalan. Pada tataran nasional, kalangan Sunni pada umumnya terhenyak dengan kemajuan pembukaan isolasi Barat terhadap Iran. Kesepakatan mengenai program nuklir Iran dicapai di Wina, Austria, (14/7/2015) untuk mengatasi kecurigaan Barat terhadap program yang dinyatakan Iran bertujuan damai tersebut, dan dengan demikian sanksi terhadap Iran dicabut, tetapi memertahankan embargo senjata dan larangan teknologi rudal balistik.

Kecurigaan Barat dan kecurigaan Sunni selama ini menemukan titik temu yang kuat, namun setelah kesepakatan ini, jalan cerita akan sedikit berbelok. Ideologi Syiah semakin merajalela, segera setelah organisasi Islam terbesar Indonesia, Nahdlatul Ulama juga dipegang kembali oleh tokoh-tokoh yang disinyalir mendukung poros Iran dan menolak dominasi poros Arab Saudi yang berpenduduk penganut Sunni. Kesepakatan ini ditetapkan dengan komitmen yang mengindahkan "garis merah" yang telah ditentukan Iran.Mengenai poin-poin yang menguntungkan Iran dalam kesepakatan itu, sebagai sebuah perkembangan yang mengkhawatirkan, secara geopolitik dan ideologis.

Implikasi yang sangat mencemaskan kaum Wahabi adalah terpilihnya Haedar Nashir dalam Muktamar Muhammadiyah 2015 lalu yang dipandang tak menaruh rasa kasihan dan pembelaan pada ekstrimisme. Ekstrimisme yang selama tiga dekade lalu disematkan kepada Iran yang distigmatisasi sebagai musuh Barat, akan mengubah peta ideologi tidak hanya di Timur Tengah. Negara-negara besar mengakui program nuklir tujuan damai Iran serta menghargai hak nuklir bangsa Iran dalam kerangka undang-undang dan konvensi internasional. Iran telah mengalami ketidakadilan yang diberlakukan Barat selama ini, laiknya sebuah tekanan yang kemudian mengubah perilaku dan orientasi ideologisnya. Penelitian Echebarria Echabe \& Fernández Guede (2006) menunjukkan pengaruh terorisme pada perilaku dan orientasi ideologis seseorang atau kelompok organisasi secara signifikan (Echabe dan Guede, 2006). 
Kebijakan politik internasional Iran mungkin akan berubah dengan kesepakatan nuklir ini. Program nuklir Iran yang semula dianggap sebagai ancaman bagi perdamaian dan keamanan dunia diluruskan menjadi obyek kerjasama Iran dengan komunitas internasional sesuai standar global. Dewan Keamanan Perserikatan Bang-Bangsa (DK-PBB) mengakui Iran sebagai negara berkekuatan nuklir tujuan damai, termasuk di bidang daur ulang bahan bakar nuklir dan pengayaan uranium. Telah terjadi perubahan fundamental dalam pola interaksi DK PBB dengan Iran setelah keluarnya resolusi DK PBB di bawah pasal 25 Piagam PBB, sembari mengingat pasal 41 dan terutama lagi pasal-pasal berkenaan dengan pencabutan sanksi sebelumnya terhadap Iran. Semua fasilitas nuklir Iran tetap beroperasi, dan tak ada satupun yang dihentikan ataupun dibekukan sebagaimana yang diinginkan sebelumnya oleh pihak lawan runding Iran. Pengayaan uranium Iran tetap dilanjutkan, dan demikian keinginan untuk menghentikan pengayaan uranium tidak terpenuhi.

Dunia keilmuan dan penelitian teknologi akan menjadikan Iran sebagai daya tarik baru bagi kalangan Muslim, selain eksotisme feminisnya. Fasilitas infrastruktur nuklir Iran tetap dipertahankan, dan tidak ada satupun sentrifugal yang disingkirkan. Aktivitas penelitian dan pengembangan semua sentrifugal utama dan mutakhir tetap dilanjutkan. Instalasi nuklir untuk produksi air berat tetap dipertahankan dan terus dikembangkan serta ditambah dengan perlengkapan, teknologi, ujicoba dan instalasi terkini melalui kerja ${ }^{-}$ sama dengan pihak-pihak lain yang memiliki teknologi mutakhir di bidang ini. Iran sebagai salah satu produsen bahan bakar nuklir, terutama uranium yang diperkaya dan air berat, akan mengakses pasar internasional. Dengan demikian maka sanksi dan pembatasan terhadap ekspor dan impor bahan bakar nuklir yang sebagian di antaranya sudah berjalan selama 35 tahun menjadi tidak berpengaruh.

Iran dan semua perangkat ideologisnya akan mengalami liberalisasi. Semua embargo ekonomi, finansial, perbankan, migas, petrokimia, perdagangan, suplai dan transportasi yang diterapkan oleh Uni Eropa dan Amerika Serikat sebagai sanksi atas program nuklir Iran akhirnya dicabut sekaligus.Tuntutan penghentian program rudal Iran, khususnya balistik, dikendurkan menjadi 
pembatasan terhadap kebijakan Iran berkenaan dengan rudal-rudal yang dapat membawa hulu ledak nuklir. Embargo senjata terhadap Iran dicabut dan diganti dengan beberapa ketentuan pembatasan. Iran diperkenankan mengimpor ataupun mengekspor sebagian produk persenjataan. Sanksi berkenaan dengan bahan berfungsi ganda dicabut, dan dengan demikian kebutuhan Iran di bidang ini akan dipenuhi melalui komisi bersama Iran dan P5+1. Mahasiswa Iran tidak lagi dikenai sanksi akademik di bidang-bidang sains yang berhubungan dengan energi nuklir.

Liberalisasi teknikal juga sama masifnya dengan liberalisasi ekonomi dan militer yang diberikan Barat. Iran bisa mengganti ideologi senjata dengan pembukaan isolasi. Embargo pesawat sipil yang sudah berjalan tiga dekade dicabut, dan dengan demikian Iran juga dapat mengakses suku cadang untuk upgrade hingga memenuhi standar keamanan. Pencairan aset keuangan Iran di luar negeri sebesar milyar dolar Amerika Serikat yang telah dibekukan dan diblokir selama beberapa tahun terakhir akibat sanksi. Bank Central Iran, perusahaan pelayaran, perusahaan minyak nasional, perusahaan transportasi minyak dan perusahaan-perusahaan lain yang bernaung di bawahnya, maskapai penerbangan Iran, dan banyak lembaga dan instansi perbankan (sekitar 800 orang dan perusahaan) dinyatakan keluar dari daftar sanksi. Banyak kalangan Wahabi di Indonesia tak paham dengan semua 'berkah' yang didapatkan Iran dan semakin sulit untuk mengandalkan teori konspirasi sebagai penjelasan tunggal atas kemajuan diplomasi nuklir ini.

Apa yang telah diberikan Barat kepada Iran adalah suatu yang di luar perkiraan negara-negara Arab di Timur Tengah. Iran mendapat peluang lebih besar untuk berkontribusi di pasar dan sektorsektor perdagangan, teknologi, keuangan dan energi.Pembatasan kerjasama ekonomi Iran di semua bidang, termasuk investasi di sektor industri migas dan petromikia, dicabut.Indonesia lantas semringah dengan hasil kepakatan nuklir Iran di Wina ini. Peluang terbukanya kerjasama luas semua pihak dengan Iran di level internasional di sektor energi nuklir tujuan damai serta pembangunan pembangkit listrik, reaktor untuk riset dan penyediaan teknologi nuklir terkini.

Implikasi politik dari perjanjian itu mencakup aturan mengenai 
pengawasan lokasi fasilitas nuklir di Iran sehingga pengawas PBB dapat meninjau lokasi militer, namun Iran bisa saja menentang pemberian akses. Sebagai gantinya, PBB mengatakan embargo senjata dan sanksi rudal hanya akan berlaku dalam lima sampai delapan tahun lagi. Namun, apabila Iran melanggar perjanjian, penjatuhan sanksi akan diberlakukan dalam 65 hari. Resolusi PBB ini akan mendukung kesepakatan yang secara otomatis akan memutuskan satu mekanisme agar seluruh sanksi Dewan Keamanan bisa secara otomatis berlaku kembali jika Iran melanggar kesepakatan itu.

Kesepakatan Wina ini mengatur bahwa enam negara adidaya, Iran dan Uni Eropa akan membentuk satu komisi bersama untuk menangani pengaduan jika ada pelanggaran. Jika negara yang mengadu itu tidak puas dengan keputusan komisi, negara tersebut bisa membawa keluhannya ke Dewan Keamanan PBB.Dewan Keamanan PBB kemudian harus mengambil suara untuk resolusi untuk tetap memberlakukan embargo dan sanksi terhadap Iran.

\section{KETEGANGAN POLITIK SAUDI DAN IRAN}

Rivalitas Sunni dan Syiah di
Timur Tengah bisa dibaca dari kuatnya persaingan Iran dan Arab Saudi dalam mengembangkan mazhab masing-masing. Saudi berusaha membangun jaringan Sunni di negara-negara Timur Tengah dengan sekte Wahabisme. Sementara Iran menggalang dan mengembangkan jaringan Syiah di Timur Tengah dengan menanamkan semangat revolusi Islam Iran. Kompetisi ideologis ini menjurus ke arah benturan perang fisik dan psikis yang cukup menelan korban jiwa. Para ahli Timur Tengah sering menyebut rivalitas agama dan politik Iran-Saudi itu sebagai Perang Dingin baru di Timur Tengah (Grumet, 2015).Para pengikut Syiah yang tinggal di Arab Saudi, seperti Nimr al Nimr, mencoba mengguncang dominasi Wahabi Saudi dari dalam. Tidak heran jika pemerintah kerajaan Arab Saudi menjatuhkan hukuman mati dan mengeksekusi pengikut Syiah itu akhir Desember 2015 (https://www. merdeka.com).

Tahun 2015, usai mengeksekusi mati 47 narapidana termasuk ulama terkenal Syiah, Syekh Nimr Baqir al-Nimr, Arab Saudi terus menuai protes dan kecaman. Republik Islam Iran jadi salah satu negara paling keras mengecam Saudi, sebab mayoritas warganya adalah 
penganut sekte Syiah (https://news. idntimes.com).

Sebagai dampak masalah eksekusi ini, warga Iran kemudian menggelar protes massal, yang berujung pada pembakaran kedutaan Saudi di Ibu Kota Teheran. Hal ini kemudian memicu putusnya hubungan diplomatik kedua negara. Penganut Syiah yang bergolak tak cuma Iran, namun juga warga Syiah di Bahrain, Yaman, dan Irak juga berdemo mengecam Saudi yang menganut mazhab Sunni.

Arab Saudi memutus hubungan dengan Iran di tengah pertikaian hukuman mati terhadap ulama Syiah terkemuka Arab Saudi, Sheikh Nimr al-Nimr. Kedua kekuatan berada pada posisi yang berseberangan dalam sejumlah konflik kawasan. Iran memperingatkan Arab Saudi akan menghadapi " pembalasan Ilahi" terkait eksekusi, dan Kedutaan Besar Saudi di Teheran diserang pengunjuk rasa yang marah.

Sejak Revolusi Islam Iran pimpinan Ayatollah Khomeini tahun 1979, Arab Saudi dan Iran menjalin hubungan diplomatik yang rumit, dilandasi saling curiga, persaingan, serta permusuhan. Pemicunya tak sekadar perbedaan mazhab Islam. Secara geopolitik, Iran dan Saudi juga bersaing untuk memengaruhi negara-negara te- tangganya dan juga terdapat kecurigaan tentang pengaruh Iran terhadap kelompok minoritas Syiah di Arab Saudi, di samping masyarakat Syiah di Bahrain, Irak, Suriah dan Lebanon. Program nuklir Iran dan kemungkinan bahwa negara itu pada suatu hari akan memiliki senjata nuklir, juga membuat khawatir Arab Saudi.

Bermula dari 1979, saat itu penguasa Arab Saudi terperanjat menyaksikan Raja Shah Mohammed Reza Pahlevi digulingkan ulama Syiah pimpinan Ayatolah Khomeini. Karena 'kecewa dan khawatir serta ngambek' dengan Republik Islam Iran, Saudi kemudian mendukung Irak dalam perang Iran-Irak pada 1980-1988. Warga Iran protes, sebab Saudi membolehkan Irak menggunakan senjata kimia. Hubungan diplomatik kedua negara ini terus memburuk dan hampir mencapai puncaknya pada 1987. Kala itu, 275 orang Iran tewas dalam bentrokan di Tanah Suci, Mekah dari total korban 402 jamaah. Rivalitas politik Iran dan Saudi ini bertahan lama karena masingmasing memiliki kekuatan sepadan, berlarut-larut dan terkunci ke dalam konflik yang bakal berlangsung hingga masa depan (Goertz dan Diehl, 1993).

Tegangan Islam politik antara 
Saudi dan Iran umumnya dilihat masyarakat dunia sebagai ketegangan kaum Muslim Sunni dan Syiah. Ada yang berpendapat bahwa seandainya Nabi Muhammad sebelum wafat tahun 632 menentukan penggantinya, mungkin semua ketegangan politik itu tidak terjadi. Tetapi karena penerus Rasullulah SAW tidak ada, kelompok Islam yang masih muda itu terpecah-belah sekitar 30 tahun setelah Muhammad SAW wafat. Sebagian besar menggabungkan diri dalam kelompok yang disebut Sunni. Kelompok kedua terdiri dari pendukung Ali bin Abi Talib, saudara sepupu dan menantu Mohammad. Kelompok itu disebut "Shi'at Ali", atau pengikut Ali, yang berkembang menjadi Islam Syiah.

Tahun 632 di Negara Madinah yang jadi masalah terutama soal politik perorangan. Sengketa berpangkal pada pertanyaan, bagaimana cara tepat menentukan pengganti Muhammad. Pakar Islam Lutz Berger dari Universitas Kiel, Jerman menambahkan, "Awalnya adalah konflik politik mengenai pengganti dan kepentingan kelompok. Konflik politik itu kemudian dijadikan masalah agama"(http://www.dw.com).

Mengenai pertikaian akan penerus Muhammad yang sah, awalnya disetujui melalui suara mayoritas adanya empat khalifah. Tahun 660, dinasti Umayah mengambil alih kekuasaan. Dalam pemilihan khalifah, bagi mayoritas pemeluk agama Islam yang penting adalah, mereka berasal dari suku Quraish, seperti halnya Muhammad. Sedangkan pendukung Ali berpendapat, pengganti harus berasal dari keluarga Muhammad. Itu dilandasi argumentasi, Tuhanlah yang menentukan Ali sebagai pengganti, dan Muhammad telah menetapkannya secara tertulis sebelum meninggal. Menurut keyakinan Syiah, Kelompok Sunni kemudian menghapus aturan tersebut dari al-Quran. Dengan demikian, timbul tuduhan pemalsuan al-Quran oleh kelompok Sunni.

Menurut Dr. Lutz Berger, Ali tidak bersedia menerima, jika dirinya tidak menjadi penerus Muhammad. Akhirnya tahun 656 ia dipilih menjadi khalifah keempat dan terakhir. Kekuasaannya hanya berlangsung lima tahun. Ali kemudian jadi korban pembunuhan. Di daerah pusat kekuasaan Islam yang baru terbentuk, yaitu Damaskus, dinasti Umayah kemudian berkuasa. Sedangkan pendukung Ali menguasai provinsiprovinsi di sekitarnya, yang sekarang 
menjadi wilayah Irak. Tahun 680 putra termuda Ali, Hussein dipilih menjadi khalifah untuk menandingi khalifah-khalifah lainnya. Tapi di tahun yang sama ia dibunuh atas perintah keluarga Umayah, kemudian dimakamkan di Karbala, yang sekarang termasuk Irak. Pembunuhan itu menjadi tonggak perpecahan antara Sunni dan Syiah. Peristiwa itu juga menjadi landasan tradisi martir yang menjadi ciri khas Syiah.

Dalam kaitan ini, sejarah mengisahkan bahwa dalam Perang Shiffi, antara kelompok Ali bin Abi Thalib dengan kelompok Mu'awiyah bin Abi Sufyan sebagai hasil dari pertikaian politik pasca kematian Khalifah Usman bin Affan. Sebagaimana di dalam sejarah, ketika Ali terpilih menjadi khalifah, ia mendapatkan tantangan dari beberapa pemuka sahabat yang ingin menjadi khalifah, di antaranya ialah Mu'awiyah bin Abi Sufyan, Gubernur Damaskus waktu itu. Mu'awiyah tidak mengakui Ali sebagai khalifah, sebagaimana juga Talhah dan Zubair.Mereka menuntut kepada Ali, agar menghukum pembunuh Khalifah Usman bin Affan, bahkan mereka menuduh Ali bin Abi Thalib turut terlibat dalam pembunuhan itu. Salah seorang pemuka pemberontak dari Mesir yang datang ke Madinah, dan kemudian membunuh Usman bin Affan, adalah Muhammad Ibn Abi Bakr, anak angkat dari Ali bin Abi Thalib. Selain itu, Ali tidak mengambil tindakan keras terhadap pemberontak, bahkan Muhammad Ibn Abi Bakr ditunjuk dan diangkat menjadi Gubernur Mesir. Pertikaian politik tersebut mencapai puncaknya dalam perang besar antara pasukan Ali bin Abi Thalib dengan pasukan Mu'awiyah bin Abi Sufyan di Shiffi (Hitti, 1974: 181-183, dan Rijal, 2010: 7).

Pasukan Ali dapat mendesak dan memukul mundur tentara Mu'awiyah, sehingga pasukan Mu'awiyah, Amir ibn al-Ash yang terkenal sebagai orang yang licik, meminta berdamai dengan mengangkat al-Qur'an ke atas. Seorang sahabat dari kelompok Ali yang bernama Qurra' mendesak Ali supaya menerima tawaran itu. Dengan permintaan itu, dicarilah kerangka perdamaian dengan mengadakan arbitrase (tahkim) di antara kedua belah pihak. Sebagai perantara, diangkat dua orang: Amir bin al-Ash dari pihak Mu'awiyah dan Abu Musa al-Asy'ari dari pihak Ali. Sejarah mencatat, bahwa dalam perjanjian damai itu, kedua belah pihak menandatangani kesepakatan untuk tidak menjatuhkan kedua 
pemuka sahabat yang bertentangan itu. Tetapi, karena kelicikan Amir bin al-Ash, arbitrase tersebut menguntungkan pihak Mu'awiyah, karena ia mengumumkan hanya menyetujui pemakzulan Ali bin Abi Thalib yang diumumkan lebih dulu oleh Abu Musa alAsy'ari, dan menolak menjatuhkan Mu'awiyah. Akibatnya, kedudukan Mu'awiyah naik menjadi Khalifah yang tidak resmi alias tidak sah. Dalam perkembangan kemudian, dengan tipu muslihat dan kelicikan oleh para musuh Khalifah Ali, akhirnya, sebagaimana terbukti dalam sejarah, Khalifah Ali bin Abi Thalib berhasil dibunuh. Ali bin Abi Thalib dibunuh ketika sedang Shalat Subuh di masjid. Dua sampai tiga hari sang khalifah ini masih bisa bertahan hidup sebelum akhirnya wafat (Hitti, 1974: 181183, dan Rijal, 2010: 7). Gugur dan syahidnya Khalifah Ali telah menjadi memori sosial-keagamaan yang membangkitkan spiritualitas kaum Syiah untuk melawan apa yang mereka persepsikan sebagai kezaliman dan kebatilan.

Berdasarkan data terbaru, ada sekitar 1,6 milyar persebaran penduduk Muslim di berbagai belahan dunia, ada sekitar 8590\% di antaranya menganut Islam Sunni. Jumlah penganut Syiah tidak diketahui dengan pasti, karena di banyak negara tidak ada sensus yang mencatat agama warganya. Selain itu, kaum Syiah yang tinggal di wilayah-wilayah yang mayoritas penduduknya non Syiah, tidak selalu mengungkapkan keyakinan mereka. Hingga sekarang, kaum Syiah adalah kelompok minoritas, yang anggotanya diperkirakan sekitar 10-15\% dari total 1,6 milyar warga Muslim di dunia.

Ilustrasi di atas sekadar menunjukkan betapa sensitif dan rentannya konflik Sunni-Syiah jika tidak dikelola dan diselesaikan dengan cara-cara etis, damai dan beradab. Dalam kenyataannya, konflik Sunni-Syiah memang tidak lepas dari dimensi agama, ideologi dan ekonomi-politik.Sejak tahun 2005, Arab Saudi telah berhasil mengirim bantuan US\$ 30 juta ke Lebanon, Irak dan Bahrain, dalam upaya membuat jaringan Sunni yang luas dibawah kontrol dan komando organisasi intelijen Arab Saudi (http://www.kompasiana. com).

Pada 2011, dengan terjadinya gejolak di pemerintahan Syria, Arab Saudi secara diam-diam lebih deras mendukung oposisi Syria dalam memerangi pemerintahan SyiahBashar al-Assad, Tapi hingga tahun 2014 tampaknya perkembangan 
situasinya makin lama makin tidak membawa keuntungan bagi Arab Saudi (US News and World Report, 2015).

Demikian juga di Libanon, gerakan politik di bawah pimpinan Sunni tidak mampu menekan kekuatan milisi Syiah - Hizbullah. Dengan keputusan AS (Amerika Serikat) keluar dari Timteng dan gelagat membaiknya hubungannya dengan Iran telah memaksa Arab Saudi naik ketengah gelanggan panggung dari pada berada dibelakang layar. Malah Saudi berniat membuat "perubahan besar" dalam hubungan dengan Amerika sebagai bentuk protes atas sikap AS atas Suriah dan mendekatnya AS ke Iran(http://www.dw.com).

Meskipun Presiden Amerika Serikat Barack Obama berikrar melindungi sekutu-sekutunya di Teluk Arab dengan kekuatan militer jika diperlukan di tengah ketegangan dengan Iran, Saudi masih khawatir bahwa AS tidak total membela Riyadh menghadapi Teheran. Hubungan AS dan sekutu-sekutunya di Teluk Arab sudah menegang setelah Obama menyepakati perundingan nuklir dengan Iran (http://www.bbc.com).

Sejauh ini, di era kepemim pinannya Obama telah berusaha untuk menempatkan tanggung jawab keamanan Timteng pada para pemimpin di kawasan itu, terutama untuk sekutunya seperti Arab Saudi yang telah digelontorkan dana miliaran dollar mesin militer oleh Amerika. Namun pada saat yang sama pemerintahan Obama juga menarik pasukan AS dari hot spot Timteng yang berbahaya itu. Akibatnya, negara-negara Arab di Teluk kurang percaya terhadap kebijakan AS di Timteng. Para analis mempertanyakan: Jika di Timteng antara Syiah dan Sunni, antara orang Arab dan orang Persia tidak bersatu, sedang Syiah dan Persia memiliki senjata nuklir, mana mungkin orang-orang Arab bisa menerima hal itu?(http://www. albayyinat.net/jwb5ta, dan http:// www.dw.com).

Konflik Saudi dan Iran itu telah membuat Barat menggeneralisir bahwa konflik Sunni-Syiah di Timur Tengah akan terus bergejolak. Tapi benarkah sumbernya soal SunniSyiah, bukan konflik sumber daya, geopolitik dan perebutan pasar senjata? Kompleksitas masalah itu rupanya saling berhimpitan dalam kasus pertikaian di Timur Tengah.

Arab bukanlah sekutu abadi AS dan Iran bukanlah musuh abadi Amerika. Realitanya adalah persaingan kepentingan abadi antara AS, Saudi dan Iran untuk bergerak 
mengamankan kepentingan masing-masing. Pada kenyataannya, sebenarnya Arab Saudi telah marah kepada AS untuk waktu yang lama. Apalagi pada 2011, AS secara aktif mendorong gelombang gerakan revolusi "Arab Spring" ke Arab Saudi. Meskipun mantan Raja Abdullah dari Arab Saudi dengan cepat dapat menstabilkan keadaan. Tapi Arab Saudi masih ingat bahwa AS berada di balik gerakan tersebut.

Pada tahun yang sama, Arab Saudi mengirim pasukan untuk menekan perlawanan anti-pemerintahan Bahrain, dan saat itu AS mengkritik Arab Saudi atas tindakan tersebut, juga tidak mendukung negara tersebut. Demikian juga pada tahun 2011, saat terjadi krisis Syria, dan angkatan bersenjata Arab dan opisisi Syria berusaha menggulingkan pemerintahan Bashar al-Assad, tetapi pada akhirnya Obama justru berkompromi dalam masalah senjata kimia Syria, sehingga membuat Arab Saudi tertekan dan marah. Namun Arab Saudi tak bisa berbuat banyak kepada Amerika, payung militernya di Timur Tengah.

Dewasa ini, AS secara aktif mempromosikan normalisasi hubungannya dengan Iran dan itu mendorong Teheran lebih leluasa dalam melaksanakan kebijakan
Timur Tengahnya. Arab Saudi berpopulasi sekitar 24 juta, 85\% faksi Sunni, dan $15 \%$ Syiah. Iran berpolulasi 85 juta dan $91 \%$ adalah berfaksi Syiah dan 7,8\% Sunni. Di luar Saudi dan Iran ada Turki yang berkepentingan memainkan peran di Timur Tengah.Tapi apa yang menjadi dasar dari konflik di Timteng? Memang banyak konflik yang mendasarinya, tapi para analis Barat umumnya menjustifikasi bahwa yang paling utama dan yang sangat memiliki koneksitas serta yang paling berakar, adalah konflik antara Syiah dan Sunni.

Justifikasi itu diperkuat dengan peran Iran dalam pertikaian internal di Irak pasca Saddam Hussein, menguatnya Hizbullah di Lebanon dan Hamas di Palestina karena dukungan Teheran. Justifikasi itu juga merujuk pada pernyataanMantan Presiden Mesir Hosni Mubarak yangmenyampaikan di acara TV pada tahun 2006, bahwa: "Banyak pengikut Syiah Mesir yang lebih setia kepada Iran daripada pada negara mereka (Mesir)" (http://www.albayyinat.net/jwb5ta, dan http://www.dw.com).

Harus diakui, konflik antara Arab Saudi dan Iran bukan hanya kontestasi antar faksi agama, tapi juga kontestasi kekuasaan. Kedua negara ini coba menggunakan 
negara-negara yang relatif lemah di wilayah ini untuk mempeluas pengaruh mereka. Tapi dengan timbulnya kekacauan dalam pemerintahan Yaman dan munculnya milisi Houthi, Arab Saudi berada di pihak yang dirugikan di medan kunci ini. Di Syria, Lebanon dan Irak, pengaruh Iran terus berkembang, bahkan membuat Arab Saudi menjadi lebih buruk.

Pertanyaanya: Lalu, dari siapa Arab Saudi akan mendapatkan dukungan yang lebih kuat lagi? Arab Saudi adalah negara terbesar dan terkaya di jazirah Arab.Tapi teknologi dan industrinya tidak pesat layaknya Mesir. Militernya memiliki peralatan yang terbaik, tapi sejauh ini strategi perangnya belum teruji. Militer Arab Saudi belum pernah mengalami tes dalam skala besar (http://www. kompasiana.com/).

Tapi Arab Saudi ragu bahwa dirinya memiliki kemampuan untuk mengendalikan situasi di Timteng. Mesir, misalnya, memiliki kekuatan politik yang kuat dan relatif stabil, meskipun bukan negara kaya. Dalam konteks ini Arab Saudi bisa membantu Kairo sebagai sekutunya di Timur Tengah. Namun Kairo saat ini bukanlah kekuatan militer yang memadai untuk menghadapi aksi Iran di kawasan Timur Tengah.
Dalam hal ini, Saudi mampu memberi Mesir lebih dari US\$ 10 milyar, sedang negara lain hanya memberi ratusan juta dollar atau mungkin hanya satu atau dua milyar dollar saja dan itu juga disesuaikan dengan kondisi yang ada. Lain lagi dengan Arab Saudi ketika memberikan Mesir US\$ 10 milyar tanpa syarat.

Meski sudah merosot ekonominya, Arab Saudi merupakan kekuatan ekonomi teratas di Timteng. Namun sebagai kekuatan politik dan sosial, Mesir masih nomor satu jika dibandingkan dengan Arab Saudi. Selama gelombang revolusi Arab Spring, Iran berusaha memengaruhi kaum Syiah untuk bersikap mendukung perubahan rezim-rezim di Timur Tengah. Di Mesir, negara yang berpengaruh di kawasan Arab itu, pemilu yang demokratis dimenangkan kelompok Ikhwanul Muslimin dan Mohammad Morsi terpilih jadi presiden. Kekuasaan Morsi mengkhawatirkan Saudi dan AS/Barat. Lalu, diam-diam Arab Saudi membantu penggulingan Morsi yang Sunni di Mesir.

Sebenarnya, sebelum Jenderal Al-Sisi menjadi Presiden Mesir, mantan Raja Abdullah dari Arab Saudi sudah menyatakan dukungan kuat untuknya. Pada 2013, setelah menjadi Menhan Mesir, Al-Sisi 
yang memimpin militer, kemudian bergerak menggulingkan Presiden Mohamed Morsi, Pada tahun 2013 itu, ketika Al-Sisi memimpin militer dalam kudeta menggulingkan pemerintahan Morsi, Arab Saudi di belakang layar memberi dukungan besar kepadanya (http://www. kompasiana.com).

Para akademisi dan analis memandang Al-Sisi mampu mempertahankan kepemimpinannya dan Mesir akan tetap stabil, sebagian besar berkat peran utama yang dimainkan Arab Saudi di belakang layar. Raja Arab Saudi menjadi kepala negara asing pertama yang mengucapkan selamat kepada AlSisi dan militer Mesir. Arab Saudi menggalang negara-negara Teluk UAE dan Kuwait untuk memberi Mesir bantuan ekonomi melebihi US\$ 12 milyar untuk melewati krisis ekonomi pada saat itu.

Sebagaimana diketahui, pada saat itu ekonomi Mesir dalam kesulitan dan negara itu semestinya sudah dalam keadaan bangkrut. Cadangan nasional Mesir telah menurun menjadi kurang dari US\$ 15 milyar ketika Sisi menjabat. Jika dipikir kembali penduduk Mesir 90 juta dengan cadangan kurang dari US\$ 15 milyar dapat dibayangkan seperti apa kondisi Mesir saat itu. Jelas Mesir sudah dalam kondisi bangkrut.

Setelah Mesir berada dalam orbit politik Saudi, pemerintah Riyadh melakukan intervensi militer ke Yaman dimana kaum Syiah berhasil merebut kekuasaan dari tangan Sunni. Masyarakat Arab Saudi tidak hanya mendukung perang baru Arab Saudi di Yaman, tetapi juga peran barunya di Timteng sebagai "Polisi", untuk mengisi kekosongan yang disebabkan ditinggalkan oleh keengganan Amerika Serikat untuk campur tangan dalam wilayah ini lagi. Yaman menjadi batu ujian Arab Saudi untuk menguji kepemimpinan dan kemampuan militernya di Timur Tengah. Saudi berharap Mesir, Yordania dan negara Teluk lainnya membantu memperkuat Saudi sebagai polisi di Timur Tengah.

Mesir diminta Saudi bergabung tanpa pamrih, tetapi Arab Saudi sangat kecewa dengan Mesir atas seluruh operasi militernya. Sebab Mesir hanya mengirim beberapa kapal patroli Bab-el-Mandeb sebagai simbolis, dan Arab Saudi percaya tindakan Mesir tidak untuk menyerang Yaman untuk membantu Arab Saudi, sebab itu hanya lebih merupakan tindakan untuk melindungi Terusan Suez yang menguntungkan Mesir. Arab Saudi sangat kecewa terhadap 
sikap Mesir tersebut(http://www. albayyinat.net/jwb5ta, dan html http://www.dw.com).

Selain itu, Arab Saudi dalam tingkat tertentu juga kecewa terhadap Pakistan, karena Arab Saudi terutama minta mereka memobilisasi pasukan.Namun Pakistan merasa hal tersebut bukan krisis besar dalam negeri Arab Saudi sendiri, melainkan di negara lain, sehingga Pakistan dengan sopan menolak. Sikap yang sama juga ditunjukkan negara-negara lain seperti Yordan dan mitra lain di Teluk, yang dikatakan memobilisasi militer nyatanya hanya untuk "pertunjukan" saja. Walhasil, aliansi Arab Saudi ini jika diukur kapasitas tempurnya sebenarnya masih sangat terbatas (Time, 2015). Sementara Iran (dan Turki) jauh lebih digdaya dalam bidang kemiliteran dan intelektualisme. Iran dan Turki memerangi ISIS yang beraliran Wahabi, dan Saudi khawatir bila ISIS tersudut, pengaruh Syiah di Irak makin kuat, sementara Turki juga berusaha memperluas pengaruhnya di Timur Tengah, seraya mengurangi peran Saudi dan Persia sekaligus. Segitiga ketegangan Saudi-Iran-Turki sebenarnya merupakan konsekuensi logis dari rivalitas ketiga kekuasan regional itu. Dengan konflik Suriah, Libya dan Yaman, situasi dunia Arab semakin hari cenderung semakin tak menentu. Yaman, Irak, Syria dan Libya situasinya memburuk, sementara ISIS masih merajalela dan mampu membangun jaringan di AS dan Eropa serta Asia, meski posisinya di Irak dan Suriah kian tersudut..

Menghadapi berbagai tantangan ini, Arab Saudi terlihat seperti putus asa dengan melihat AS dan Iran membuka dialog dan mencapai kesepakatan awal kerangka kerjasama. Arab Saudi pernah menggunakan minyak sebagai alat untuk menghukum Iran, namun hal ini juga menimbulkan kerusakan dan kerugian besar bagi Arab Saudi sendiri. Arab Saudi harus membayar harga yang makin lama makin mahal dan berat menghadapi Iran yang kini sudah bebas dari sanksi ekonomi PBB.

Jika Arab Saudi dan Iran bisa lebih dekat satu sama lain, kemungkin besar sangat bermanfaat bagi stabilitas Timteng. Para analis Timteng melihat konflik dan persaingan ini disebabkan melemahnya negara-negara besar di Timteng. Bukan dikarenakan vakum kekuatan AS/Barat setelah Presiden Barack Obama menarik kekuatan militer dari Irak dan Afghanistan, tapi lebih disebabkan 
oleh munculnya faktor yang tak terkendali yang disebabkan melemahnya kemampuan negaranegara Arab itu untuk menghadapi tantangan di kawasan. Selain itu, dengan adanya konfrontasi geostrategis antara Arab Saudi dan Iran, konflik agama dan ideologis cenderung meruncing. Kaum Sunni di negara-negara seperti Syria dan Irak memerlukan pasukan militer untuk melindungi kepentingan sekte mereka sendiri. Sedangkan kelompok Syiah pun demikian. Tarik-menarik kepentingan dan persaingan dalam rangka menancapkan kuku kekuasaan antara kaum Sunni dan Syiah kian merumitkan masalah di Timur Tengah.

Para analis melihat, munculnya pemerintahan yang kuat di negaranegara seperti Irak, Syria, Yaman dan Mesir, memungkinkan konflik agama diperlemah, dipangkas dan bisa membawa situasi di Timteng ke arah stabilitas. Dalam kaitan ini, Arab Saudi sebagai "pemimpin" Dewan Kerja Sama Teluk (GCC) di satu sisi harus bertanggung jawab atas keamanan dan kepentingan negara-negara Teluk. Dan di sisi lain sebagai kekuatan ekonomi terkuat di Timteng dan sebagai kekuatan utama yang paling berpengaruh di wilayah tersebut. Arab Saudi harusbersikap tegas untuk bisa memengaruhi arah masa depan Timteng ke arah stabilitas dan perdamaian.

Bagaimanapun kacaunya wilayah Timur Tengah, situasi tersebut hanya dapat dikendalikan dan diredam kalau Arab Saudi dan Iran bisa mencapai kesepakatan dengan jalur diplomasi, bukan perang. Dalam hal ini, Indonesia sebagai negara Muslim terbesar dalam Organisasi Konferensi Islam (OKI) bisa berkontribusi dengan cara menjembatani komunikasi kedua negara tersebut agar stabilitas dan kedamaian regional dapat terwujud. Jika saja Persia dan Arab para pemimpinnya mampu berdialog dengan baik niscaya kata damai dapat disepakati. Konflik Sunni-Syiah sendiri bukanlah konflik yang diletupkan oleh Saudi dan Iran, melainkan oleh pihak ketiga yang tidak menghendaki stabilitas dan perdamaian terwujud di Timur Tengah. Saudi dan Iran tentunya sadar dan paham bahwa selama era Perang Dingin, Timur Tengah menjadi ajang bisnis senjata, pertarungan geopolitik dan perebutan sumberdaya minyak dan gas yang tiada tara. Sehingga sekiranya Saudi dan Iran tidak mencapai kesepakatan damai, hampir pasti instabilitas dan konflik di Timur Tengah terus membara, 
dan persoalan lain seperti krisis kemanusiaan di Palestina, fenomena ISIS, dan pergolakan di Lybia, Yaman dan Suriah belum jelas akhirnya.

Berangkat dari paparan di atas, bisa dimengerti bahwa implikasi politik dari persaingan sengit Iran dan Saudi di Timur Tengah adalah ketegangan dan pembelahan yang makin tajam antara kaum Sunni dan Syiah di dunia Islam. Pertarungan politik berhimpitan dengan isu agama, dan geostrategis, yang menyeret Timur Tengah masuk ke dalam konflik berlarut antara Saudi dan Iran entah sampai kapan.

\section{Implikasi Ideologis}

Kesepakatan program nuklir yang disetujui oleh Iran dan enam negara adidaya ini membuat Arab Saudi khawatir pengaruh Iran akan semakin menguat di kawasan Timur Tengah. Bagi Arab, kesepakatan ini akan mengubah orientasi ideologis mereka dan juga sikap politik serta sikap kultural mereka terhadap Barat dan China. Implikasi ideologis akan tetap terasa, tanpa disadari. Tidak ada satu pun organisasi atau masyarakat atau bahkan bangsa yang terbebas atau netral secara ideologis. Ideologi menggerakkan vibrasinya pada berbagai situasi, mulai dari Revolusi Amerika
(Baylin, 1992), ke organisasi yang non-ideologis sekalipun (Czarniawska-Joerges, 1988), dari diagnosa medis (Gartner, Harmatz, Hohmann, Larson, \& Gartner, 1990), atau ketika kita mengonsumsi suatu produk (Treise, Weigold, Conna, \& Garrison, 1994), hingga ke soal-soal anggaran (Wilensky, 1974).

Hampir semua kegiatan manusia memiliki aspek ideologis, baik itu berbentuk motif maupun kecemasan dan ketakutan. Dalam aspek mitologi misalnya, ketakutan masyarakat Nusantara terhadap hantu kuntilanak atau sundelbolong juga bisa dilihat dari aspek orientasi ideologi, pun demikian halnya dengan hantu-hantu vampir atau zombie di masyarakat Barat. Bagi masyarakat Nusantara vampir bukanlah sosok yang menyeramkan, terutama vampir perempuan. Zombie terlihat lucu karena relatif lamban. Mungkin dalam pandangan masyarakat barat kuntilanak tak ubahnya makhluk eksotis dan menggemaskan.

Kecemasan atas kesepakatan nuklir Iran mungkin terasa di beberapa negara jazirah Arab. Namun dalam persepsi ideologis umat Islam Sunni di Indonesia, kesepakatan nuklir Iran ini dilihat secara berbeda.Apa yang dipersepsikan sebagai hantu yang menakutkan 
di Arab mungkin berbeda dengan hantu eksotis di Indonesia. Kesepakatan Iran secara ideologis diprediksi akan menjadikan Timur Tengah menjadi "kawasan yang lebih berbahaya" jika kesepakatan tersebut terlalu menguntungkan bagi Iran. Saudi dan negaranegara sekutunya di kawasan Teluk khawatir bahwa kesepakatan yang akan berujung pencabutan sanksi ekonomi Iran akan berakibat pada meningkatnya dukungan Iran terhadap negara-negara rival Saudi di Timur Tengah. Analisis tambahan menunjukkan bahwa jalur ideologis yang menghubungkan kecemasan, persepsi berbahaya di dunia memiliki dampak kuat pada keseluruhan diri penempatan kiri-kanan dari jalur yang menghubungkan tindakan menghindari, dan munculnya persepsi kompetitif di tengah belantara ketidakpastian. Kalangan Sunni dan kalangan Wahabi, pada khususnya, merasakan hantu Iran yang menggemaskan bisa mengarah ke tindakan serious offence.

Kesepakatan Nuklir Iran ini menimbulkan kecemasan tersendiri bagi Wahabi yang semakin hari kecenderungan ditekan oleh pihak Barat dan oleh kalangan Muslim tradisional semakin menguat. Narasi yang acap kali dibangun, Wahabi sebagai kaum ekstrimis dan pelaku tindakan yang berlebihlebihan. Teori Greenberg, Solomon, \& Pyszczynski (1997) menganggap otoritarianisme dan konservatisme sebagai sumber ideologi bagi munculnya motif kolektif (untuk merobek pandangan pengaturan sosial sebagai stabil, adil dan dapat diprediksi) dan motif pribadi (untuk mengatasi kecemasan eksistensial). Otoritarianisme dan konservatisme Wahabi akan semakin dipermalukan dengan kesepakatan nuklir Iran di Wina ini.

Saudi, yang mayoritas penduduknya merupakan Muslim Sunni, dan Iran yang mayoritas Syiah telah lama menjadi rival di kawasan Timur Tengah. Konflik di Yaman, menjadi ajang pertempuran antara Saudi yang mendukung Presiden Yaman dan pemberontak Syiah Houthi yang didukung oleh Iran. Pengaruh ideologis dari kesepakatan nuklir ini selanjutnya akan menyumbang bagi membesarnya konflik. Motivasi bagi munculnya ideological rigidity dan konflik sosial bahkan bisa muncul dalam dunia manajemen yang sempit (Peterson \& Flanders, 2002), apatah lagi dalam dunia politik dan keagamaan (Jost, Napier, Thorisdottir, Gosling, Palfai, \& Ostafin, 2007).

Konflik Syiah Houthi di Yaman 
akan semakin melebar dan membesar dan semakin membuat Saudi terjepit. Sebagai tetangga Iran dalam empat dekade terakhir, kaum Wahabi di Arab belajar bahwa kebaikan (terhadap Iran) hanya akan membuat mereka menanggung konsekuensinya. Politik tanpa belas kasihan akan terjadi terhadap kaum Syiah dimana pun sebagai akibat dari konstelasi politik yang tidak sepadan yang diberikan oleh Barat melalui kesepakatan nuklir bagi Iran di Wina ini. Situasi menyesakkan ini tentu akan mengakibatkan kaum Wahabi pun tidak tinggal diam dan akan bereaksi secara ekstrim dengan memainkan kekerasan keagamaan di Indonesia.

Ancaman dan ketersudutan akan mengakibatkan bangkitnya motivasi reaktif yang berlebihan (Nash, McGregor, \& Prentice, 2011). Para pejabat dan masyarakat Iran mengaku mendukung kesepakatan ini, meski menyatakan bahwa Iran tidak dapat dipercaya untuk menepati kesepakatan tersebut. Selain konflik di Yaman, Riyadh juga menganggap Iran mendukung Presiden Suriah, Bashar al-Assad dan Hizbullah di Libanon.Saudi menilai, hal ini merupakan bukti bahwa Iran ingin memperlebar kekuasannya ke negara sekutu Syiah di Timur Tengah. Di Indonesia, ketersudutan ini memang belum terasa sekarang, namun beberapa tahun kedepan akan ada reaksi ekstrim apabila pemerintah menjalin hubungan politik dan dagang yang semakin mesra dengan Iran.

Selama ini kaum Wahabi sangat asertif dalam menolak ideologi Syiah di berbagai kawasan, termasuk di Indonesia. Abu Jibriel (2015), misalnya, sangat aktif menyerang Syiah dengan mengklaim bahwa mereka bukan Islam dan menyebarkan politik eksklusi yang serius terhadap Syiah, yang tak pernah ditunjukkan sebelumnya oleh kaum Sunni manapun di Nusantara. Kesepakatan nuklir telah menuai kritikan dari wartawan, ulama dan pakar di Saudi, utamanya karena sekutu utama Riyadh, Washington kini berbagi dukungan dengan rival mereka di Tehran. Iran membuat kekacauan di dunia Arab dan hal ini akan terus terjadi setelah kesepakatan nuklir. Negara Sunni di kawasan teluk mungkin akan mengurangi kepercayaan mereka terhadap Amerika dan mengubah fokus mereka ke Rusia yang kelihatannya mulai memberikan tempat bagi tumbuhnya politik Islam di bagian timur Eropa. Namun tidak demikian halnya di Indonesia. Mereka bisa saja membenci Syiah, 
namun suka dengan sisi feminim Iran yang sangat eksotik.

Kalangan Wahabi Indonesia pun saat ini sedang menghadapi perpecahan internal yang tak terperikan dengan munculnya fenomena ISIS (Islamic State of Iraq and Syria) yang telah menguras darah dan keringat serta finasial mereka dalam menghadapi perang sesama Wahabi yang melelahkan ini. Komitmen ideologi memang senantiasa dipertaruhkan di antara risiko dan faktor yang melindungi suatu kaum (Laor, Wolmer, Alon, Siev, Samuel, \& Toren, 2006), maka ada kemungkinan reaksi ekstrim akan terjadi terhadap kalangan Syiah di beberapa kawasan yang konfliktual dan bermusuhan, hostile, khususnya di Indonesia. Negeri ini memiliki reputasi buruk dalam hal perlindungan terhadap kaum Syiah dengan munculnya berbagai kasus intoleransi dan bentrokan berdarah yang menyedihkan dimana banyak anak-anak dan orang tak berdaya terlempar ke tempat-tempat penampungan transito yang tak manusiawi dan tak bisa pulang ke rumahnya selama bertahun-tahun.

Kesepakatan nuklir Iran ini akan muncul dalam bentuk-bentuk kultural yang dominan selain kontestasi ideologis di Indonesia. Jika kemenangan ideologis Iran terjadi di Indonesia, maka kalangan Sunni yang mayoritas akan mempersepsikan hal ini sebagai imperialisme kultural. Imperialisme kultural dan kecemasan masyarakat akan mengakibatkan munculnya perubahan hukum dan ideologi (ideological realignment) secara signifikan (Peller, 1997).

Penulis memprediksikan bahwa kemungkinan adanya reformasi ideology di tubuh kaum Wahabi di Indonesia dalam menyesuaikan dirinya dengan modernitas. Ilmu pengetahuan dan teknologi akan tersembur dari Iran secara masif dengan terbukanya isolasi Iran ini. Kaum Wahabi yang saat ini mengalami kekalahan yang akut dan tak pernah menang dalam setiap upaya perebutan kekuasaan akan berpikir ulang dan menyesuaikan gairah kekuasaannya dengan perhitungan ideologis dalam manajemen pergerakan mereka. Ideological realignment ini akan menuntut kaum Wahabi untuk menurunkan tensi ekstrimismenya atau akan terancam hilangnya pendukung tradisionalnya dari kalangan Sunni di Nusantara yang beragam dan kosmopolit ini.

\section{IRAN DAN TURKI}

Kesepakatan nuklir Iran ini dipandang oleh kaum Wahabi 
merupakan cara Amerika dan Barat untuk menghapus citra positif Turki yang diyakini akan membangkitkan the glory of the past khilafah. Bagi kaum Wahabi di Indonesia, citra Arab Saudi bersifat kurang baik dibanding Turki, meski mereka membela Saudi dalam hal pemberontakan Syiah Hauthi di Yaman. Sebagaimana terlihat melalui media Arrahmah.com yang mengutip artikel penulis Yordan, Ihsan Al Faqih, 26 Desember lalu pada media Achahed.

Produk Domestik Nasional Turki di tahun 2013 mencapai 100M dolar Amerika, menyamai pendapatan gabungan 3 negara dengan ekonomi terkuat di Timur Tengah; Arab Saudi, Uni Emirat arab, Iran, dan ditambah dengan Yordan, Suriah dan Lebanon.Posisi Turki dengan ketokohan Recep Tayyip Erdogan telah berhasil membawa negerinya melakukan lompatan ekonomi yang besar, dari rangking 111 dunia ke peringkat 16 , dengan rata-rata peningkatan $10 \%$ pertahun, yang berarti masuknya Turki kedalam 20 negara besar terkuat (G-20) di dunia. Tahun 2023 merupakan tahun pembangunan Negara Turki Modern yang sudah dicanangkan oleh Erdogan, yang ditargetkan adalah Turki menjadi kekuatan politik dan ekonomi nomer
1 di dunia! Airport Internasional Istanbul adalah bandara terbesar di Eropa yang menampung 1260 pesawat setiap harinya, ditambah Bandara Shabiha yang menampung 630 pesawat setiap hari. Turkish Airline, yang sering ditumpangi oleh para mujahidin ketika akan ke Afghanistan atau ke Suriah, meraih peringkat maskapai penerbangan terbaik di dunia dalam 3 tahun berturut-turut. Kegagalan kudeta militer di Turki pada pertengahan Juli 2016 lalu membuktikan kuatnya kepercayaan rakyat kepada Erdogan serta kuatnya kewibawaan, dan pengaruh Erdogan pada masyarakat Turki yang sudah memilih jalan demokrasi. Dalam kurun 10 tahun, Turki telah menanam 770 juta pohon Harjia dan berbuah.Untuk pertama kali Turki di masa modern ini memproduksi sendiri Tank baja, pesawat terbang dan pesawat tempur tanpa awak, serta satelit militer modern pertama yang multi fungsi.

Pada aspek saintis, Erdogan dalam 10 tahun pemerintahannya telah mendirikan 125 universitas baru, 189 sekolah baru, 510 rumah sakit baru dan 169.000 kelas baru yang modern, sehingga rasio siswa perkelas tidak lebih dari 21 orang. Ketika krisis ekonomi menimpa Eropa dan Amerika, universitas- 
universitas Eropa dan Amerika menaikkan uang kuliah.Sedangkan Erdogan membebaskan seluruh biaya kuliah dan sekolah bagi rakyatnya dan menjadi tanggungan negara. Dalam 10 tahun terakhir, pendapatan perkapita penduduk Turki yang dahulunya hanya 3500 dolar pertahun, meningkat pada tahun 2013 menjadi 11.000 dollar pertahun, lebih tinggi dari perkapita penduduk Prancis. Erdogan juga menaikkan nilai tukar mata uang Turki 30 kali lipat. Hal ini tidak seberapa jika dibandingkan dengan Iran. Di Turki, negara sedang mengupayakan dengan sungguh-sungguh membiayai 300.000 ilmuwan melakukan penelitian ilmiah untuk menuju tahun 2023.

Posisi Turki secara geopolitik juga menjadi harapan besar bagi kaum Wahabi di Indonesia. Di antara keberhasilan politik terbesar Turki adalah keberhasilan Erdogan mendamaikan dua bagian Cyprus yang bertikai. Ia juga melakukan pembahasan damai dengan partai Buruh Kurdistan untuk menghentikan pertumpahan darah, dan meminta maaf kepada Armenia, sehingga menyelesaikan permasalahan yang sudah menggantung sejak 6 dasawarsa. Di negara Turki, gaji dan upah meningkat mencapai 300\%. Dan gaji pegawai baru meningkat, dari 340 lira Turki menjadi 957 lira. Selain itu, jumlah pencari kerja menurun dari $38 \%$ menjadi $2 \%$. Di Turki, anggaran pendidikan dan kesehatan, mengungguli anggaran pertahanan, dan gaji guru sebesar gaji dokter. Hal inilah yang membuat kunjungan Presiden Turki, Erdogan, disambut histeris oleh kalangan Wahabi di Indonesia dan mereka mencemooh Jokowi yang tidak bersedia menerimanya untuk shalat jumat bersama di Masjid Istiqlal Jakarta awal Agustus 2015.

Jika dibandingkan dengan Iran yang memiliki banyak ilmuwan nuklir, maka di Turki telah dibangun 35 ribu laboratorium IT dan database modern yang melatih pemuda militan Turki. Erdogan menutupi defisit anggaran yang mencapai 47 milyar dolar.Sebelumnya cicilan terakhir hutang Turkike IMF adalah 300 juta dolar pada Juli lalu. Bahkan Turki meminjami IMF yang jelek namanya itu sebesar 5 milyar dolar.Disamping itu Erdogan juga menambah cadangan devisa negara sebesar 100 milyar dolar. Jika sepuluh tahun lalu, ekspor Turki hanya 23 milyar dolar.Sekarang meningkat menjadi 153 milyar dolar, mencapai 190 negara. Yang paling banyak adalah mobilyang kedua peralatan elektronik. Setiap 
3 perangkat elektronik di Eropa, satunya adalah produk Turki.

Dalam hal lingkungan hidup yang sustainable, Pemerintah Erdogan mengawali pengolahan sampah menjadi pembangkit tenaga listrik, yang digunakan oleh sepertiga penduduk Turki. Dan energi listrik sudah dinikmati 98\% penduduk Turki. Erdogan pernah duduk berhadapan dengan seorang anak perempuan yang usianya masih 12 tahun, tampil dalam siaran langsung televisi, berdebat dan berdiskusi tentang pembangunan Turki masa depan. Beliau hormati kecerdasan dan semangat anak tersebut. Sekaligus beliau didik anak-anak Turki keteladanandalam berdebat dan berdiskusi serta membaca masa depan. Erdogan adalah teman Israel, begitu menurut kaum sekuler Arab. Erdogan memberikan tamparan keras kepada Israel, dan dia memaksa Israel meminta maaf karena kasus kapal Marmara yang ditembak Israel, 2010 silam. Turki juga berikan syarat pencabutan embargo Gaza untuk menerima permintaan maaf tersebut. Erdogan berikan kritikan tajam terhadap orang-orang yang bertepuk tangan terhadap pidato Simon Perez dalam pertemuan Ekonomi dunia, dan beliau berkata sebelum keluar ruangan dan pulang ke Turki: "Memalukan kalian bertepuk tangan terhadap pidato ini, padahal Israel telah membantai ribuan anak dan wanita di Gaza..."

Pada era dunia yang semakin demokratis, kaum Wahabi melihat Erdogan dengan penuh harapan. Erdogan menyemprot para demonstran penentangnya dengan air. Tidak menembak mereka dengan pesawat tempur, atau rudal atau bom-bom molotov. Erdogan menolak anak gadisnya membuka hijab saat sekolah. Maka beliau kirim anaknya sekolah di Eropa agar tetap berhijab, sebelum hijab dibolehkan di kampus-kampus Turki. Kebangkitan Turki yang demikian dahsyat ini membuat harapan akan bangkitnya khilafah menjadi sesuatu yang niscaya bagi kaum Wahabi Jihadi di Indonesia. Wahabi jihadi adalah kaum yang berbeda dengan Wahabi Shururi atau Wahabi Takfiri. Bagi kaum Wahabi Jihadi, khilafah Abubakar Ibrahim Al-Baghdadi (ISIS) bukanlah khilafah yang sebenarnya. Itu adalah khilafah palsu, dan Turki akan bangkit (kembali) menjadi khilafah yang sebenarnya.

Dalam diplomasi dunia, Erdogan satu-satunya kepala negara bersama istrinya mengunjungi Burma dan bertemu dengan kaum Muslimin di sana dari ka- 
wasan Myanmar yang dapat bencana. Keberanian Turki ini telah memuaskan rasa terzhalimi yang dialami Muslim Rohingya. Erdogan menghidupkan kembali pengajaran Al Quran dan Hadits di sekolah-sekolah negeri, setelah hilang selama hampir 90 tahun, dihilangkan pemerintah sekuler. Erdogan menetapkan kebebasan berhijab di kampuskampus Turki dan di parlemen. Erdoganlah pemimpin Muslim yang membuat lampu di jembatan gantung terbesar di dunia di pantai laut hitam dengan penerangan yang sangat besar bertuliskan "Bismillahirrahmanirrahim.." Padahal, salah satu negara Arab membuat pohon natal terbesar di dunia dengan menelan dana mencapai 40 juta dolar. Rasa respek kaum Wahabi jihadi di Indonesia terhadap Arab musnah sudah.

Bagi kaum Wahabi jihadi di Indonesia, Turki adalah harapan baru di ufuk kebangkitan modern Islam. Erdogan mengembalikan pembelajaran bahasa Ustmaniyah yang berhuruf Arab di sekolahsekolah negeri. Erdogan melepas pawai 10 ribu anak-anak Muslim yang berumur 7 tahun di jalan-jalan Istambul, dengan penuh bangga anak-anak tersebut akan memulai kewajiban shalat berjamaah dan menghafal al-Quran. Barangkali keadaan seperti inilah yang dirindukan oleh Wahabi Jihadi di Indonesia.

\section{Referensi}

\section{Buku}

Bailyn, B. (1992). The ideological origins of the American Revolution.Harvard University Press.

Czarniawska-Joerges, B. (1988). Ideological control in nonideological organizations. Praeger Publishers.

Echebarria Echabe, A., \& Fernández Guede, E. (2006). Effects of terrorism on attitudes and ideological orientation. European Journal of Social Psychology, 36(2).

Garber, M. B. (1997).Vested interests: Cross-dressing and cultural anxiety. Psychology Press.

Gartner, J., Harmatz, M., Hohmann, A., Larson, D., \& Gartner, A. F. (1990). The effect of patient and clinician ideology on clinical judgment: A study of ideological countertransference. Psychotherapy: Theory, Research, Practice, Training, 27(1), 98. 
Jibriel AR, Abu Muhammad.(2015). Fakta Syiah Bukan Islam. Jakarta: Arrahmah Publishing. Jost, J. T., Napier, J. L., Thorisdottir, H., Gosling, S. D., Palfai, T. P., \& Ostafin, B. (2007). Are needs to manage uncertainty and threat associated with political conservatism or ideological extremity?. Personality and social psychology bulletin, 33(7), 989-1007.

Laor, N., Wolmer, L., Alon, M., Siev, J., Samuel, E., \& Toren, P. (2006).Risk and protective factors mediating psychological symptoms and ideological commitment of adolescents facing continuous terrorism. The Journal of nervous and mental disease, 194(4), 279286.

Nash, K., McGregor, I., \& Prentice, M. (2011). Threat and defense as goal regulation: from implicit goal conflict to anxious uncertainty, reactive approach motivation, and ideological extremism. Journal of personality and social psychology, 101(6), 1291.

Parry-Giles, Trevor. (1994). "Ideological anxiety and the censored text: Real livesat the edge of the union 1." Critical Studies in Media
Communication 11.1 (1994): 54-72.

Peller, G. (1997). Cultural imperialism, white anxiety, and the ideological realignment of Brown. Race, Law, and Culture: Reflections on Brown Vs. Board of Education, 190-220.

Peterson, J. B., \& Flanders, J. L. (2002). Complexity management theory: Motivation for ideological rigidity and social conflict. Cortex, 38(3), 429-458.

Punamäki, Raija Leena. "Can ideological commitment protect children's psychosocial well being in situations of political violence?." Child development 67.1 (1996): 55-69.

Treise, D., Weigold, M. F., Conna, J., \& Garrison, H. (1994). Ethics in advertising: Ideological correlates of consumer perceptions. Journal of Advertising, 23(3), 59-69.

Weber, C., \& Federico, C. M. (2007). Interpersonal attachment and patterns of ideological belief. Political Psychology, 28(4), 389-416.

Wilensky, H. L. (1974). The welfare state and equality: Structural and ideological roots of public expenditures (Vol. 140). Univ of California Press. 


\section{Internet}

https://www.merdeka.com/dunia/ begini-kronologi-alasan-iranarab-saudi-selalu-tidak-akur. html

https://news.idntimes.com/world/ rizal/15-rentetan-pertikaianantara-arab-saudi-dan-iransepanjang-sejarah-1

http://www.dw.com/id/sunnidan-syiah-bersaing-sejakdulu/a-16189563.

http://www.kompasiana.com/ makenyok/apa-latar-belakangkonflik-islam-sunni-vssyiah-di-timur-tengah2_559c693d169373ae05ef062a

Pada 2 April 2015, website "US News and World Report" mempublikasikan sebuah artikel berjudul "The Obama Doctrine/" : "Biarlah Timteng berperang untuk perangnya sendiri" (Let the Middle East Fight Its Own Wars).

http://www.dw.com/id/arabs a u d i - a n c a m - ja u hi amerika/a-17178087 http://www.bbc.com/indonesia/ dunia/2015/05/150515_dunia_ saudi_as

http://www.albayyinat.net/jwb5ta. html

http://www.dw.com/id/syiahsunni-kebencian-mengakardi-arab-saudi/a-18492316. http://www.kompasiana. com/makenyok/apa-latarbelakang-konflik-islam-sunnivs-syiah-di-timur-tengah2_559c693d169373ae05ef062a

http://www.albayyinat.net/jwb5ta. html

http://www.dw.com/id/syiah-sunnikebencian-mengakar-di-arabsaudi/a-18492316.

http://www.kompasiana.com/ makenyok/apa-latar-belakangkonflik-islam-sunni-vssyiah-di - timur-tengah 4_559c693d169373ae05ef062a 